\title{
P. E. Teaching Innovation in Chinese Colleges and Universities
}

\author{
Li Qin
}

Nanchang Institute of Science \&Technology, Nanchang 330108,China

Keywords: higher education P. E. teaching; current situation; problems; strategies

\begin{abstract}
In order to adapt to the needs of the new century talents, the full implementation of quality education, college physical education should according to the movement technology as the center of the phenomenon existed in the past, adhere to the three aspects, based on the reform and innovation. To promote the reform of college physical education in China is conducive to promoting the establishment of a new teaching theory, update the concept of teachers, and through quality education, training students' ability of independent thinking, the courage to explore and innovate, to guide the students to form the correct sports values.

At the present stage, the education departments at all levels of our country pay much attention to the reform of teaching methods, and formulate corresponding policies and regulations. In the process of teaching, teachers should take the dominant position of the students, arouse the enthusiasm and creativity of the students, and actively practice the teaching methods. This study aims at the present situation of physical education in colleges and universities in China, finds out the existing problems, and puts forward some countermeasures from the point of view of innovation education.
\end{abstract}

\section{The present situation of $\mathbf{P}$. E. education in Colleges and universities of China}

Our country arranges more than 10 years of P.E. education class in the P.E. education teaching process, and it has formulated the related document. The sports management organization of colleges and universities set up schools, physical education teachers pre-service and in-service training after institutions, and organize a large number of full-time study to develop a wide range of conditions for the development of standards, improve the teaching system of physical education curriculum. However, many students say goodbye to sports when they graduate, 10 years of physical education has not made the concept of lifelong sports deeply rooted in the hearts of the people, and did not develop the skills and good habits of physical exercise. The results show that the physical quality of college students is obviously decreased.

The proportion of young people suffering from modern disease is significantly higher than ten years ago: heart disease, stroke, diabetes, high blood pressure, osteoporosis, depression, obesity and other diseases tend to younger. Up to now, our country has carried on the nationwide student physique health test result to show: the modern disease related to the young people lack of the physical exercise. The physical health level of the primary and middle school students and college students in our country shows obvious disharmony, which is shown in the following aspects: high stature and low quality; the improvement of the level of morphological development and the poor physical quality. In addition, the rate of myopia is increasing year by year, especially in primary and secondary school students, the rate of myopia increased obviously. The quality of the vital capacity, speed, explosive power, endurance showed a downward trend and so on .

The reasons for the decline of students' physical quality are various. In the majority of primary and secondary school physical education in our country, the content of physical education is old and single, the form is monotonous and boring. The traditional physical education is mainly based on 
the physical skills and pass on ability, and the modern innovative teaching ideas have not been able to penetrate into the practice of physical education. Curriculum content can not meet the physical and mental development and needs of students, not to mention creativity, students can not use after graduation. For example, the shot, discus, javelin, jumping repeated set up from the primary school to university, but few people after graduation or extracurricular them as a means of lifelong exercise. At present, at Chinese stage of primary school, middle school, high school, university this seemingly all-round development of sports teaching can not help students develop the habit of exercise in the growth process, which leads to students' lack of physical fitness, physical decline.

\section{Problems in P. E. Education in Colleges and universities of China}

College sports teaching materials and teaching content obsolete. At present, China's college sports teaching mostly teach sports athletics skills preparation, teaching content uniformity, year-round constant, does not reflect the real needs of today's social development training content of sports teaching, inconsistent with the age, poor usability. In addition, most of the teaching materials of physical education are based on the single item teaching and training of sports, which is out of the training goal of modern physical education. Finally, the creation of teaching materials does not take into account the cultivation of students' personality, specialty and interest, which is not conducive to the formation of a set of suitable training methods and exercise habits. These problems directly lead to college sports teaching step by step, only focus on the basic knowledge, basic skills, emphasis on exercise intensity and density, while ignoring the needs of the development of students.

The fuzzy goal of P. E. education in colleges and universities. The first step is to set the teaching goal. The university sports teaching goal of our setting in the implementation failed to combine personal goals and social goals, to student's physical, psychological, and social development together, to their interests and hobbies combined with sports and sports idea, which can not achieve better students' personal value and social value. In the current physical education in colleges and universities, colleges and universities should be based on the guiding ideology of health first to set the teaching objectives.

The unreasonable structure of P. E. education teaching team in Colleges and universities. The survey found that many colleges and universities physical education teachers structure is irrational. First of all, the proportion of teachers with high degree of education is less, which restricts the improvement of physical education and scientific research in colleges and universities. In addition, the knowledge structure of college sports teachers tend to unreasonable, relatively concentrated in the traditional professional basketball and volleyball, football and so on. It is very difficult to introduce more fashionable items such as hip hop, belly dance, yoga, sports dance, etc.. These problems have seriously affected the construction of college physical education teachers.

\section{Reform and exploration of P. E. education in colleges and universities}

Reform and exploration of P. E. education curriculum system in Colleges and Universities. For a long time, subject to the constraints of China's curriculum management system and the impact of the development of competitive sports, sports courses in colleges and universities are mostly competitive sports as the main teaching content. The contents of each section of the physical education courses are not closely linked with each other, and the phenomenon of low-level repetition and obsolescence is not conducive to the cultivation of students' interest. The goal of physical education is too limited to enhance the physical fitness of students, ignoring the habit of physical training and the cultivation of lifelong sports concept, which is not in conformity with the physical and psychological characteristics of students, and deviates from the purpose of modern 
physical education. The reform and innovation of physical education teaching content system is a breakthrough in the reform of physical education in china. The contents of sports teaching should be based on primary school; junior primary school to the high school development in transition period, should be the foundation and special, focus on high school should be the basic foundation; additional expertise, and the focus should be settled in the specialty, the university stage, students should master the basic methods and skills of two or more exercise, positive improve the level of sports development, sports talents, which lay a solid foundation of lifelong physical education. According to the law of cognitive and physical and mental development of young people, the teaching objectives of each teaching stage should be gradual, that is to say, each student should master a sports skill in each stage of physical education, so as to lay the foundation for lifelong physical education.

Reform and innovation of physical education teaching objectives in colleges and universities. College physical education is the highest level of school physical education. Therefore, physical education should be based on the cultivation of students' lifelong sports consciousness and ability. In particular, only after the realization of the primary, junior high and high school levels of teaching objectives, the highest level of higher education teaching objectives can be achieved smoothly. The university stage is the key period for the development of the students' body shape and the formation of the exercise habit. This is a key point for students, changing from individual value to social value, therefore, college teachers should teach and urge the students to master the lifelong exercise, to cultivate their lifelong sports consciousness, make them form a good habit of lifelong exercise, and improve the students' physical health and mental health. Undoubtedly, the most important thing is to help college students master and meet the needs of their own sports skills and sports, in order to cultivate students' love of physical exercise and lifelong sports habits.

Reform and innovation of physical education teaching contents in colleges and universities. The reform and innovation of physical education teaching content is one of the key points in teaching reform. With the development of the times, the majority of students are more interested in recreational sports and leisure sports. Therefore, college physical education reform should focus on the type of curriculum, teaching syllabus, teaching programs, and constantly update the teaching content; should try to provide a variety of courses, so that students can choose according to their interest in the study of the interest of the combination of learning, so as to develop interest into a hobby.

Reform and innovation of physical education teaching mode in colleges and universities. On the basis of the reform of teaching objectives and teaching contents, the teaching reform of colleges and universities should gradually form and perfect a set of reasonable teaching mode which can adapt to different units and different types. This set of teaching mode of PE teaching in colleges and universities will lead to diversified development, including the training of physical and mental health and lifelong sports consciousness; traditional content and new content with new sports, increasing attention, dance, rhythmic and other recreational activities; the main teaching materials and teaching aids combined, emphasize the students' personal interest, with interest as the center guide self perfection; classroom teaching and the extracurricular activities combined; the general teaching and multimedia teaching methods combined, to enhance the fun sports knowledge of three-in-one; the evaluation for the students' motivation, process and effect, make the process of sports learning process become the interaction between subject and object of teachers and students, make students learn through evaluation. In addition, through the organization of sports associations, clubs, games, competitions and other forms of cooperation with the teaching model to stimulate students' sense of competition, to develop students' interest in sports and lifelong sports awareness. 
Attaching importance to the construction of physical education facilities and the cultivation of physical education teachers in colleges and universities. In order to deepen the reform of physical education, it is necessary to make full use of the sports facilities and equipment, and a large number of high educated, knowledgeable and professional experts and a team of physical education teachers. Therefore, the reform of physical education in colleges and universities must have a certain teaching facilities, but also need a number of new physical education teachers in line with the development of the new century.

High level sports teaching facilities to support the high level of physical education. On the one hand, the school sports teaching facilities need to be open without affecting the school physical education. In colleges and universities for the student movement, training, group activities to provide adequate sports facilities, equipment and venues; on the other hand, the stadium opening should not profit as the only objective, considering the students' capacity, the need for students to foreign. A high level of physical education to promote a high level of teachers. College teachers are the engine of teaching reform. The way out for the reform of physical education in colleges and universities is the key to the reform. As the physical education teachers in colleges and universities, should firmly establish the lifelong physical education thought, constantly update their teaching philosophy in the teaching, constantly sum up and explore; always give yourself, accept new knowledge, master new skills. Physical education teachers should strengthen their own cultural quality, and constantly improve the theoretical level and teaching ability, which is one of the important contents of the current physical education reform. In addition, the implementation of teacher training and continuing education projects in colleges and universities can optimize the knowledge structure and degree structure. Colleges and universities to increase investment in talent and research, improve the scientific research ability, innovation ability, it can help the development of physical education teaching.

\section{Conclusion}

The reform of physical education in colleges and universities is the only way to achieve the goal of physical education in colleges and universities, to complete the basic task of teaching and to enhance the teaching effect. In order to cultivate the habit of lifelong sports, college P. E. teachers should take the lead in carrying out the concept of lifelong education in teaching. Practice has proved that there is a good physical education teachers, good physical education. Physical education teachers in Colleges and universities not only impart knowledge, but also help students to develop their life style and life orientation. The sports teaching of various colleges and universities should stick to try, bold innovation, strive for the teaching goal, the selection of teaching materials, teaching mode and teaching methods, evaluation system and personnel training and other aspects of the reform put forward more deep and frontier strategies.

\section{References}

[1]Jia-Fan C. The Innovation of P. E. Teaching Content and Method in College and University[J]. Sichuan Sports Science, 2004.

[2]Liao X Q. Communicative Language Teaching Innovation in China: Difficulties and Solutions.[J]. Communicative Competence, 2000:20.

[3] Li D. Potential and Problems of Communicative, Language Teaching in China[M]. LAP LAMBERT Academic Publishing, 2014.

[4] Huang W M, Department M E, University X. Analysis of High- level Teaching Reform and 
Innovation in Private Colleges and Universities in China[J]. Journal of Weinan Normal University, 2015.

[5] Chen L U. A Probe into the Cultivation of Students' Innovation in P.E. Teaching at General Universities[J]. Journal of Beijing University of Physical Education, 2002.

[6] Zha C H, Xie L H, Zhang X R. Research on Main Influential Factors of Students'Ability to Compose Aerobics[J]. Journal of Beijing Sport University, 2006.

[7] Min B B, Zhang Z J. Information Attainment of University P.E.Teachers and Innovation of Teaching[J]. Journal of Beijing Teachers College of Physical Education, 2004.

[8] Lin C. Study of Information Attainment and Constitution of College Teachers Under Background of “Internet + ”[J]. Heilongjiang Researches on Higher Education, 2016. 